\title{
Comparing the spectral components of laser Doppler flowmetry and photoplethysmography signals for the assessment of the vascular response to hyperoxia
}

\author{
Comparando as componentes espectrais de sinais de fluxometria por laser Doppler e \\ fotopletismografia para a avaliação da resposta vascular à hiperóxia \\ Henrique Silva ${ }^{1,2}$, Mariana Bento ${ }^{2}$, Helena Vieira ${ }^{2}$, L. Monteiro Rodrigues ${ }^{1,2}$ \\ ${ }^{1}$ CBIOS - Universidade Lusófona's Research Center for Biosciences and Health Technologies, Lisboa, Portugal \\ ${ }^{2}$ Pharmacol. Sc Depart - Universidade de Lisboa, Faculty of Pharmacy, Lisboa, Portugal \\ E-mail: henrique.silva@ulusofona.pt
}

\begin{abstract}
The skin is an ideal organ to record complex vascular signals, with laser Doppler flowmetry (LDF) and photoplethysmography (PPG) being commonly used quantification techniques. Hyperoxia is a common provocation stimulus, although many questions remain unanswered regarding its effect on microcirculation. In recent years much attention has been given to the mathematical modelling of physiological signals, with component analysis being a common approach. We aimed to characterize the LDF and PPG spectral profiles using wavelet transform (WT) to evaluate their components' response to a $100 \%$ oxygen provocation on skin microcirculation. We recorded LDF and PPG signals from the toes of 10 healthy subjects (20.5 \pm 3.1 years old, after giving informed consent) before, during and after breathing an atmosphere of $100 \%$ oxygen. Signals were decomposed in their main components with the WT. Six components were identified in both signals (cardiac, respiratory, myogenic, sympathetic, endothelial NOdependent and endothelial NO-independent) in identical spectral positions. The cardiac, respiratory and myogenic activities increased during hyperoxia in both signals, while endothelial activities gave different responses. These discrepancies suggest that these techniques measure different phenomena and, therefore, may not be entirely interchangeable. These results reinforce the usefulness of WT in decomposing complex physiological signals.
\end{abstract}

Keywords: component analysis, wavelet transform, physiological signal, LDF, PPG.

\begin{abstract}
Resumo
A pele é um órgão ideal para gravar sinais vasculares complexos, sendo a fluxometria por laser Doppler (FLD) e a fotopletismografia (FPG) técnicas de quantificação vulgarmente utilizadas. A hiperóxia é um estímulo de provocação comumente utilizado, embora muitas questões permaneçam sem resposta quanto ao seu efeito sobre a microcirculação. Nos últimos anos muita atenção tem sido dada à modelação matemática de sinais fisiológicos, sendo a análise de componentes uma abordagem comum. O nosso objetivo foi o de caracterizar os perfis espectrais de FDL e FPG usando a transformada de wavelet (TW) para avaliar a resposta dos seus componentes a uma provocação de oxigénio a 100\% sobre a microcirculação da pele. Foram registados sinais de FLD e FPG nos dedos dos pés de 10 indivíduos saudáveis $(20,5 \pm 3,1$ anos), após terem dado o seu consentimento informado, antes, durante e após a respiração de uma atmosfera de oxigénio a 100\%. Os sinais foram decompostos nas suas componentes principais com a TW. Seis componentes foram identificadas em ambos os sinais (cardíaca, respiratória, miogénica, simpática, endotelial dependente de NO e endotelial independente de NO) em posições espectrais idênticas. As atividades cardíaca, respiratória e miogénica aumentaram durante a hiperóxia em ambos os sinais, enquanto as atividades endoteliais originaram respostas diferentes. Estas discrepâncias sugerem que estas técnicas medem fenómenos diferentes e, portanto, podem não ser totalmente substituíveis. Estes resultados vêm reforçar a utilidade da TW na decomposição de sinais fisiológicos complexos. Estes resultados vêm reforçar a utilidade da TW na decomposição de sinais fisiológicos complexos. As atividades cardíaca, respiratória e actividades miogicas aumentou durante a hiperoxia em ambos os sinais, enquanto que as actividades endoteliais deu respostas diferentes. Estas discrepâncias sugerem que estas técnicas medem fenómenos diferentes e, portanto, pode não estar totalmente substituíveis. Estes resultados vêm reforçar a utilidade do WT na decomposição de sinais fisiológicos complexos.
\end{abstract}

Palavras-chave: análise de componentes, transformada de wavelet, sinais fisiológicos, FLD, FPG 


\section{Introduction}

The skin is an ideal organ to record several complex physiological signals, since it allows noninvasive measurements, and also because of its large area ${ }^{(1)}$. Vascular signals are among the most commonly recorded, either for clinical or research purposes, and are useful in a wide variety of areas, from experimental dermatology (2) to cardiovascular physiology ${ }^{(1)}$ to psychology ${ }^{(3)}$. The use of provocation tests, either local or systemic, is a commonplace in vascular research, with the intent to increase the sensibility of measuring techniques and reduce variability in the evoked responses ${ }^{(4)}$. One provocation of particular interest, consists in inhaling oxygen at different fractions ${ }^{(5)}$. While hypoxia is a well-studied stimulus, hyperoxia is not, and many questions remain unanswered in spite of being a focus of intense research. There are several different techniques that allow quantitative and qualitative assessment of skin perfusion, although optical techniques are commonly preferred due to their simplicity. Among these, laser Doppler flowmetry (LDF) has been broadly used for several decades ${ }^{(6)}$. Recently, technical advances ranging from higher sensibility to reduced instrument (?) cost have given photoplethysmography (PPG) a new interest ${ }^{(7)}$. In recent years, much attention has been given to the mathematical modeling of physiological signals, including vascular signals, allowing the extraction of deeply imbedded critical features. Such features include time variability, fractal organization, unpredictability and chaotic profile, among others ${ }^{(8,9)}$. One common approach to explore the complex features of a signal consists of its decomposition in its main components, i.e. oscillations of different time frequencies which relate to the activity of different tissues or organs ${ }^{(8)}$. The fast Fourier transform is a classic method of signal decomposition, however, it suffers from low resolution when examining low frequency behaviors. A suitable alternative with considerable higher resolution is the wavelet transform (WT) ${ }^{(10)}$. One persistent challenge in the analysis of vascular signals is the identification of the frequency limits of the different components. We aimed at characterising the LDF and PPG spectral profiles with the WT evaluate skin microcirculatory component responses to a $100 \%$ oxygen provocation.

\section{Materials and methods}

Several physiological signals were noninvasively re-

\section{Introdução}

A pele é um órgão ideal para registas diversos sinais fisiológicos complexos, pelo facto de permitir medições não invasivas, bem como por possuir uma grande área (1). Os sinais vasculares estão entre os mais comumente registados, quer para fins clínicos quer de investigação, sendo úteis numa larga variedade de áreas, da dermatologia experimental ${ }^{(2)}$, fisiologia cardiovascular ${ }^{(1)}$ à psicologia ${ }^{(3)}$. A utilização de testes de provocação, locais ou sistémicos, é um lugar comum em investigação vascular, com o intuito de aumentar a sensibilidade das técnicas de medição e de reduzir a variabilidade nas respostas evocadas ${ }^{(4)}$. Uma provocação de particular interesse, consiste na inalação de oxigénio a diferentes frações ${ }^{(5)}$. Enquanto a hipóxia é um estímulo bem estudado, a hiperóxia não o é, tendo sido um foco de intensa pesquisa, ainda que muitas questões continuem sem resposta. Existem várias técnicas diferentes que permitem a avaliação quantitativa e qualitativa da perfusão cutânea, embora técnicas ópticas sejam geralmente preferidas devido à sua simplicidade. Entre estas, a fluxometria por laser Doppler (FLD) tem gozado de considerável sucesso desde há várias décadas ${ }^{(6)}$. Recentemente, avanços técnicos variando desde um aumento de sensibilidade a uma redução de custo deu um novo interesse à fotopletismografia (FPG) ${ }^{(7)}$. Nos últimos anos, muita atenção tem sido dada à modelação matemática de sinais fisiológicos, incluindo sinais vasculares, permitindo a extração de características importantes incorporadas em profundidade. Tais características incluem a variabilidade temporal, organização fractal, imprevisibilidade e perfil caótico, entre outros ${ }^{(8,9)}$. Uma abordagem comum para explorar as características complexas de um sinal consiste na sua decomposição nas suas principais componentes, ou seja, oscilações de diferentes frequências temporais e que se relacionam com a actividade de diferentes tecidos ou órgãos ${ }^{(8)}$. A transformação rápida de Fourier é um método clássico de decomposição de sinais, no entanto, sofre de baixa resolução ao explorar fenómenos de baixa frequência. Uma alternativa adequada com considerável maior resolução é a transformada de wavelet (TW) ${ }^{(10)}$. Um desafio persistente na análise de sinais vasculares é a identificação dos limites das frequências das diferentes componentes. O nosso objetivo foi o de caracterizar os perfis espectrais de FDL e FPG com a TW para avaliar a resposta das suas componentes a uma provocação de oxigénio a $100 \%$ sobre a microcirculação da pele.

\section{Materiais e métodos}

Foram registados vários sinais fisiológicos de forma não 
corded from 10 young healthy subjects, both sexes (20.5 \pm 3.1 years old), according to previously defined inclusion and non-inclusion criteria ${ }^{(4)}$ while performing a $100 \%$ oxygen breathing test. The test was carried out after a 10 minute acclimatization period, while seated comfortably in a temperature and humidity controlled room $\left(23 \pm 1{ }^{\circ} \mathrm{C}, 40-60 \%\right.$ humidity). The test consisted of three phases, each with a 10 minute duration - resting (Phase I), provocation (Phase II) and recovery (Phase III). During provocation, a 100\% oxygen atmosphere (AirLiquide, Portugal) was inhaled through a facemask. All procedures were performed in accordance with the Declaration of Helsinki and subsequent amendments ${ }^{(11)}$.

Electrical heart activity was recorded with electrocardiography (ECG, lead I) (PLUX Biosignals, Portugal) from both palms. The thorax diameter oscillations were recorded with pneumography (PNG) (PLUX Biosignals, Portugal) (piezoelectric sensor), placed around the thorax on the projection of the xyphosternal joint. Foot skin perfusion was recorded with LDF and PPG sensors, placed on the toes of both feet. Two reflection PPG sensors (PLUX Biosignals, Portugal) measured pulse blood volume changes on the third toes, while LDF probes (PF5010, Perimed, Sweden) measured blood flow on the second toes. ECG, PPG and PNG sensors were connected to a microprocessor board (BITalino Plugged) (PLUX Biosignals, Portugal) and signals collected at a $100 \mathrm{~Hz}$ sampling rate. LDF signals were acquired with a different system (Periflux PF5010, Perimed, Sweden) and collected at a $32 \mathrm{~Hz}$ sampling rate.

The raw signals were then processed in MATLAB (Mathworks, USA) with a WT toolbox, after downsampling to $32 \mathrm{~Hz}$. Two-dimensional (2D) WT-based frequency spectra were then created for each signal, and from visual inspection, the frequency of highest amplitude $\left(f_{h}\right)$ and frequency range were identified for each main activity band. The LDF components were previously identified - cardiac $(0.6 \mathrm{~Hz}$ to $2 \mathrm{~Hz})$, respiration $(0.15 \mathrm{~Hz}$ to $0.6 \mathrm{~Hz})$, myogenic activity in the vessel wall $(0.052 \mathrm{~Hz}$ to $0.15 \mathrm{~Hz})$, sympathetic activity $(0.021 \mathrm{~Hz}$ to $0.052 \mathrm{~Hz})$, NO-dependent endothelial activity $(0.0095 \mathrm{~Hz}$ to $0.021 \mathrm{~Hz})$ and NO-independent endothelial $(0.0050-0.0095 \mathrm{~Hz})^{(12)}$. For each signal, each component activity was calculated as each component's area under the curve (AUC) divided by the AUC of the total frequency spectrum. The $\mathrm{f}_{\mathrm{h}}$ from different signals was compared using the Mann-Whitney $U$ test for independent samples. The activity of each signal's component was compared between phases with the Wilcoxon signed rank test. In all statistical tests, a $p<0.05$ level was adopted as significant. invasiva em 10 indivíduos jovens e saudáveis, de ambos os sexos (20,5 $\pm 3,1$ anos de idade), de acordo com critérios de inclusão e não-inclusão previamente definidos ${ }^{(4)}$, durante a realização de um teste de respiração de oxigénio a $100 \%$. O teste foi realizado após um período de aclimatização de $10 \mathrm{~min}$, com os indivíduos sentados confortavelmente, num ambiente de temperatura e humidade controlados $\left(23 \pm 1{ }^{\circ} \mathrm{C}, 40-60 \%\right.$ de humidade). O teste consistiu em três fases, cada uma com uma duração de 10 min - repouso (fase I), provocação (fase II) e recuperação (fase III). Durante a provocação, foi inalada uma atmosfera de oxigénio a $100 \%$ (Air Liquide, Portugal) através de uma máscara facial. Todos os procedimentos foram realizados de acordo com a Declaração de Helsínquia e emendas posteriores ${ }^{(11)}$.

A atividade elétrica do coração foi registada por eletrocardiografia (ECG, derivação I) (Plux Biosignals, Portugal) nas palmas de ambas as mãos. As oscilações do diâmetro do tórax foram registados com pneumografia (PNG) (PLUX Biosignals, Portugal) (sensor piezoeléctrico), colocado em torno do tórax na projecção da articulação esternoxifóide. A perfusão da pele do pé foi gravado com sensores de FLD e FPG, colocados na face inferior dos dedos dos pés. Dois sensores de FPG de reflexão (Plux Biosignals, Portugal) mediram as variações de volume do pulso de sangue na face inferior dos terceiros dedos dos pés, enquanto que duas sondas de FLD (PF5010, Perimed, Suécia) medieram o fluxo sanguíneo nos segundos dedos. Os sensores de ECG, FPG e PNG estavam ligados a uma placa microprocessadora (BITalino plugged) (Plux Biosignals, Portugal) e os sinais foram recolhidos a uma frequência de amostragem de $100 \mathrm{~Hz}$. Os sinais FLD foram adquiridos com um sistema diferente (Periflux PF5010, Perimed) a uma frequência de amostragem de $32 \mathrm{~Hz}$.

Os sinais em bruto foram então processados em Matlab (Mathworks, EUA) com uma "toolbox" de TW, depois de sofrerem subamostragem para $32 \mathrm{~Hz}$. Foram então criados, para cada sinal, espectros bidiemensionais (2D) de frequência com base na TW e, por inspeção visual, foi identificada a frequência de maior amplitude $\left(f_{h}\right)$ e gama de frequências para cada banda de atividade principal. As componentes do FDL foram já identificadas - cardíaca $(0,6 \mathrm{~Hz}$ a $2 \mathrm{~Hz})$, respiratória $(0,15 \mathrm{~Hz}$ a $0,6 \mathrm{~Hz})$, atividade miogénica na parede do vaso $(0,052$ $\mathrm{Hz}$ a $0,15 \mathrm{~Hz})$, atividade simpática $(0,021 \mathrm{~Hz}$ a 0,052 $\mathrm{Hz})$, atividade endotelial dependente de $\mathrm{NO}(0,0095 \mathrm{~Hz}$ a $0,021 \mathrm{~Hz}$ ) e atividade endotelial independente de NO $(0,0050-0,0095 \mathrm{~Hz})^{(12)}$. Para cada sinal, a atividade de cada componente foi calculada como a área sob a curva de cada uma das componentes dividida pela AUC do espectro total de frequência. $\mathrm{A} \mathrm{f}_{\mathrm{h}}$ de sinais diferentes foi comparada pelo teste U de Mann-Whitney para 


\section{Results and Discussion}

The mean frequency spectra for each recorded signal are displayed in Figure 1. From the visual inspection of the frequency spectra, six activity bands were identified in both LDF and PPG signals. Regarding the ECG and PNG signals, several bands are visible, but only one main band was attributed to a particular activity in each case. The mean frequency of highest amplitude and range of the identified bands are shown in Table 1. amostras independentes. A atividade das componentes de cada sinal foi comparada entre fases com o teste Wilcoxon para amostras não emparelhadas. Em todos os testes estatísticos foi adoptado um valor $\mathrm{p}<0.05$.

\section{Resultados e discussão}

Os espetros de frequência média para cada sinal registado são apresentado na figura 1. Por inspecção visual

A

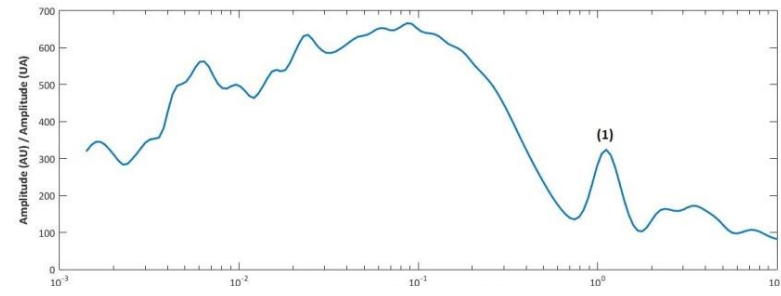

B

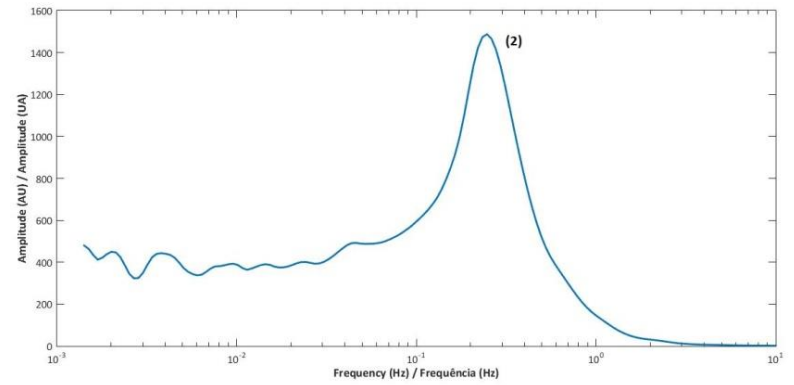

C

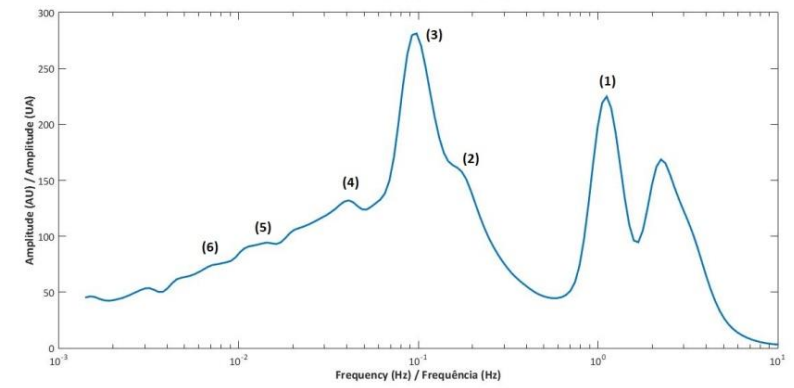

$\mathrm{D}$

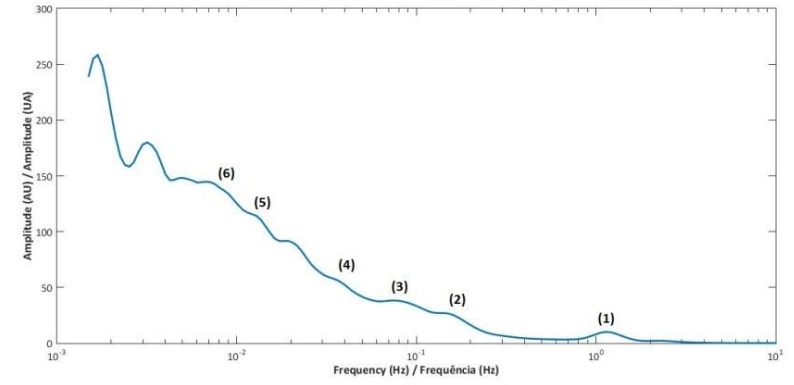

Figure 1/ Figura 1 - Mean frequency spectra of the ECG (A), PNG (B), PPG (C) and LDF (D) signals.

Espectros de frequência médios dos sinais de ECG (A), PNG (B), FPG (C) e FLD (D). 
A cardiac band was visible in both the ECG $\left(f_{h}=1.18\right)$, LDF $\left(f_{h}=1.12\right)$ and PPG $\left(f_{h}=1.11\right)$ signals at similar ranges, with $f_{b}$ showing no statistical differences between them. Whereas in the ECG this cardiac band relates to the electrical activity of the heart, in LDF and PPG it is explained by the transmission of the arterial pulse to microcirculatory blood vessels ${ }^{(13)}$. The first harmonic of the cardiac band also appears on this frequency spectra as a high amplitude band $\left(\mathrm{f}_{\mathrm{h}}=2.3\right)$. A respiratory band was visible in both PNG $\left(f_{h}=0.24\right)$, LDF $\left(f_{h}=0.16\right)$ and PPG $\left(f_{h}=0.19\right)$ signals at similar ranges. $\mathrm{f}_{\mathrm{h}}$ differs considerably between the PNG and the vascular signals, although not significantly. This discrepancy can be due to the fact that the respiratory band does not appear individualized in the LDF and PPG frequency spectra, but rather partly merged to a lower frequency band (myogenic), which hinders its analysis ${ }^{(14)}$. Although the respiratory band is more clearly visible in the PPG frequency spectra, this reason also seems to apply to this signal. Four low frequency bands were visible in LDF and PPG frequency spectra at comparable $f_{h}$, with no significant differences between signals. The myogenic band is due to the spontaneous, although regulated, oscillatory contraction of the vessels' smooth muscles, an activity termed 'vasomotion' ${ }^{(14)}$. The sympathetic band is related to the local effect of the sympathetic nervous system on the vessel wall ${ }^{(15)}$. Two endothelial bands were identified, and are presumably due to a dual effect of the endothelium - the release of chemical mediators such as NO or others ${ }^{(12)}$. dos espetros de frequência, seis bandas de atividade foram identificados em ambos os sinais de FPG e FLD. Quanto aos sinais de ECG e PNG, várias bandas são visíveis, mas apenas uma banda principal foi atribuída, em cada caso, a uma determinada atividade. A frequência média de maior amplitude e a gama das bandas identificadas são apresentadas na tabela 1 .

Uma banda cardíaca foi observada nos sinais de ECG $\left(f_{h}=1,18\right)$, FLD $\left(f_{h}=1,12\right)$ e FPG $\left(f_{h}=1,11\right)$ em intervalos semelhantes, sem que $f_{h}$ mostrasse diferença estatística entre eles. Considerando que, no ECG esta banda cardíaca se deve à atividade eléctrica do coração, em FLD e FPG ela é explicada pela transmissão da pulsação arterial aos vasos sanguíneos da microcirculação (13). O primeiro harmónico da banda cardíaca também aparece nestes espetros de frequência como uma banda de elevada amplitude $\left(f_{h}=2,3\right)$. Uma banda respiratória foi observada em ambos os sinais de FLD $\left(f_{h}=0,16\right)$, FPG $\left(f_{h}=0,19\right)$ e PNG $\left(f_{h}=0,24\right)$ em intervalos semelhantes. $A f_{h}$ difere consideravelmente entre o sinal de PNG e os sinais vasculares, embora não significativamente. Esta discrepância pode ser devida ao facto de que a banda respiratória não surge individualizada nos espetros de FLD e FPG, mas sim, parcialmente fundida com uma banda de frequência mais baixa (miogénica), o que dificulta a sua análise ${ }^{(14)}$. Embora a banda respiratória seja mais claramente visível no espetro de FPG, o mesmo fenómeno também se parece aplicar a este sinal. Quatro bandas de baixa frequência foram observados nos espetros de FLD e FPG com $f_{h}$ com-

Table 1/ Tabela 1 - fh (range) of frequencies for each component of the LDF, PPG, ECG and PNG signals, obtained by WT. Statistical comparisons between fh from different signals $(\mathrm{p}<0.05)$. fh (intervalo) das frequências de cada componente dos sinais de FLD, FPG, ECG e PNG, obtidos com TW. Comparação estatística entre fh entre diferentes sinais $(p<0.05)$.

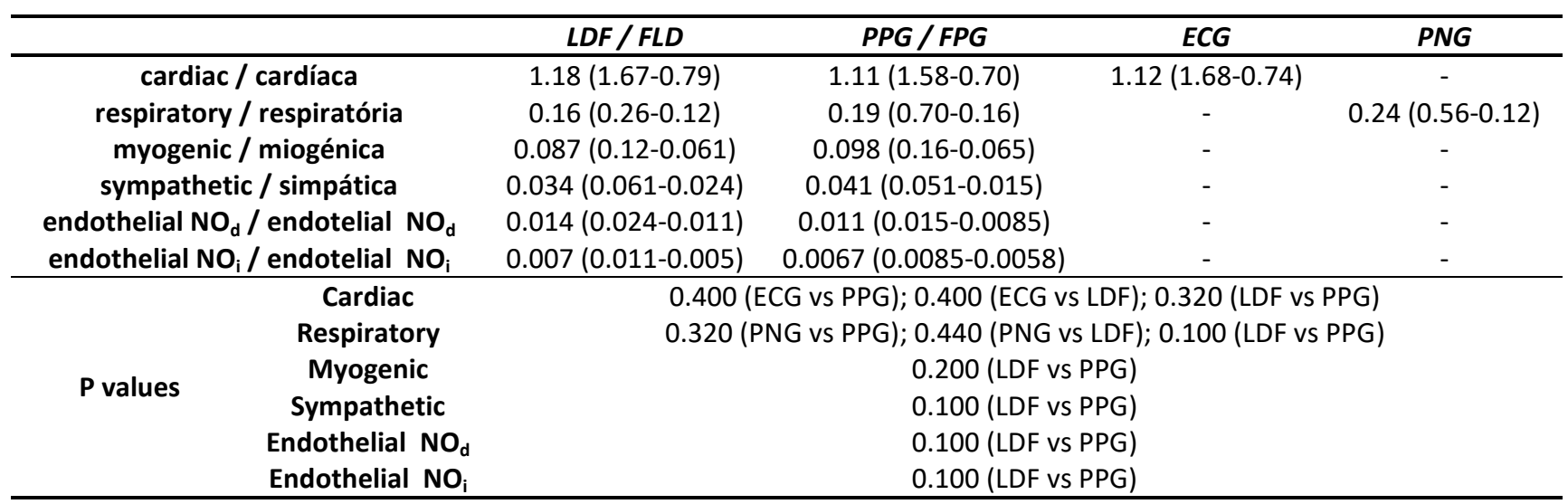


Table 2 shows the mean blood flow value and activity of each band for the LDF and PPG signals during the three phases of the protocol. As expected, blood flow decreased significantly when assessed with both techniques, due to the induced hyperoxia. Given the amplitude ratios each signal displays, LDF is mainly of endothelial origin, whereas PPG signal is more of myogenic origin. Although the spectral positions of their composing bands were similar, their behaviour showed paráveis, sem diferenças significativas entre os sinais. A banda miogénica deve-se à contração oscilatória espontânea, apesar de regulada, do músculo liso dos vasos sanguíneos, uma atividade denominada 'vasomotricidade' ${ }^{(14)}$. A banda simpática está relacionada com o efeito local do sistema nervoso simpático na parede do vaso ${ }^{(15)}$. Duas bandas endoteliais foram identificadas, e são presumivelmente devidas a um efeito dual do endotélio - a libertação de mediadores químicos tais como NO e outros ${ }^{(12)}$.

Table 2/ Tabela 2 - Mean (sd) values of each LDF and PPG signals component activity, for all phases of the protocol. Statistical comparison for Phase I (NS - non significant; * $-\mathrm{p}<0.05$ ) Média (dp) da atividade de cada componente dos sinais de FLD e FPG, para todas as fases do protcolo. Comparação estatística com a fase I (NS - não significativo; * p < 0.05)

\begin{tabular}{|c|c|c|c|c|c|c|}
\hline \multirow{2}{*}{ Component } & \multicolumn{3}{|c|}{$L D F / F L D$} & \multicolumn{3}{|c|}{$P P G / F P G$} \\
\hline & Phase I & Phase II & Phase III & Phase I & Phase II & Phase III \\
\hline \multirow{2}{*}{ Raw signal } & $20.3(14.2)$ & $15.2(10.4)$ & $18.7(17.3)$ & $114.7(16.4)$ & $80.6(13.5)$ & $83.5(13.2)$ \\
\hline & - & $0.030 *$ & NS & - & $0.023^{*}$ & $0.045^{*}$ \\
\hline \multirow{2}{*}{ cardiac / cardíaca } & $2.4(1.4)$ & $2.8(1.3)$ & $2.2(1.2)$ & $19.7(9.4)$ & $17.4(7.3)$ & $14.6(5.8)$ \\
\hline & - & $0.038 *$ & NS & - & NS & $0.013^{*}$ \\
\hline \multirow{2}{*}{ respiratory / respiratória } & $5.5(3.1)$ & $7.1(3.0)$ & $4.5(1.5)$ & $9.7(3.7)$ & $13.7(4.7)$ & $6.2(3.7)$ \\
\hline & - & $0.028^{*}$ & NS & - & $0.005^{*}$ & $0.037^{*}$ \\
\hline \multirow{2}{*}{ myogenic / miogénica } & $16.0(7.8)$ & $16.9(7.5)$ & $14.7(5.3)$ & $28.7(13.8)$ & $30.9(12.2)$ & $23.7(9.1)$ \\
\hline & - & NS & NS & - & NS & $0.028^{*}$ \\
\hline \multirow{2}{*}{ sympathetic / simpática } & $19.9(5.1)$ & $19.9(3.8)$ & $22.5(4.9)$ & $25.0(6.3)$ & $23.0(5.8)$ & $22.8(7.9)$ \\
\hline & - & NS & NS & - & NS & NS \\
\hline \multirow{2}{*}{ endothelial $\mathrm{NO}_{d} /$ endotelial $\mathrm{NO}_{\mathrm{d}}$} & $29.3(5.9)$ & $27.9(4.8)$ & $27.7(4.5)$ & $9.2(4.6)$ & $6.9(3.6)$ & $15.2(6.8)$ \\
\hline & - & NS & NS & - & NS & $0.037^{*}$ \\
\hline \multirow{2}{*}{ endothelial $\mathrm{NO}_{\mathrm{i}} /$ endotelial $\mathrm{NO}_{\mathrm{i}}$} & $28.5(8.9)$ & $26.8(6.1)$ & $29.0(7.9)$ & $7.5(3.8)$ & $9.1(4.3)$ & $7.5(3.4)$ \\
\hline & - & NS & NS & - & NS & NS \\
\hline
\end{tabular}

differences over the different phases. The cardiac activity increased significantly during Phase II in LDF, but decreased non significantly in PPG. The respiratory activity increased significantly in both signals, indicating an increased transmission to the vasculature of the hemodynamic changes caused by increased ventilation (14). Although not significantly, the myogenic activity increased in both signals, which can be due to a direct stimulatory effect of hyperoxia on the vascular wall, as mentioned elsewhere ${ }^{(16)}$. The sympathetic activity was maintained in the LDF signal, while it decreased without significance in the PPG signal. It is also proposed that hyperoxia modulates sympathetic nerve tone ${ }^{(17)}$, but that is not evident in these results. The $\mathrm{NO}_{\mathrm{d}}$ activity decreased in both signals. Although this decrease was not statistically significant, it is supported by previous results which suggests that hyperoxia inhibits NO synthase and creates reactive oxygen species (ROS) which react with and destroys $\mathrm{NO}$, thereby decreasing the $\mathrm{NO}$-mediated vasodilation ${ }^{(18)}$. As for the $\mathrm{NO}_{\mathrm{i}}$ activity, it showed a decrease in LDF but an increase in PPG. This discrepancy can be explained by differences in the depths of measurements of both techniques, as vessels at different depths show differences in calibre and, therefore, may respond differently to the same stimulus.
A Tabela 2 mostra o valor do fluxo sanguíneo médio e a atividade de cada banda para os sinais de FLD e FPG durante as três fases do protocolo. Como esperado, o fluxo sanguíneo diminuiu significativamente quando avaliado com ambas as técnicas, devido à hiperóxia induzida. Dados os rácios de amplitude que cada sinal exibe, a FLD é principalmente de origem endotelial, enquanto que o sinal FPG sobretudo de origem miogénica. Embora as posições espectrais das bandas que as compõem foram semelhantes, o seu comportamento mostrou diferenças nas diferentes fases. A atividade cardíaca aumentou significativamente durante a fase II na FLD, mas não diminuiu significativamente na FPG. A atividade respiratória aumentou significativamente em ambos os sinais, o que significa um aumento da transmissão para a vasculatura das alterações hemodinâmicas provocadas pelo aumento da ventilação ${ }^{(14)}$. Embora não significativamente, a atividade miogénica aumentou em ambos os sinais, que pode ser devido a um efeito estimulador directo de hiperóxia na parede vascular, tal como referido previamente ${ }^{(16)}$. A atividade simpática foi mantida na FLD, ao passo que diminuiu sem significância na FPG. Foi também proposto que a hiperóxia modula o tónus nervoso simpático ${ }^{(17)}$, mas tal não é evidente nestes resultados. A atividade $\mathrm{NO}_{\mathrm{d}}$ di- 
The PPG cardiac, respiratory, myogenic and $\mathrm{NO}_{\mathrm{d}}$ activities did not return to their baseline values, as observed from the significant differences between Phases III and I. Regarding LDF, all activities returned to baseline values during Phase III. A recent study showed that the low frequency components of LDF and PPG are positively correlated, however, no provocation test was applied, and results were recorded in the supine position. ${ }^{(19)}$ Our results therefore suggest that (1) although these signals give similar information in their raw form, a more detailed analysis such as WT suggests they may be measuring different phenomena and, therefore, they may not be entirely interchangeable; and that (2) provocation tests can change the spectral organization of these signals, which may explain the observed discrepancies.

\section{Conclusions}

These results reinforce the usefulness of the WT in decomposing complex physiological signals. In particular, they highlight the complexity of the vascular response to $100 \%$ oxygen, which seems to be dependent on the depth of measurement. Although they give similar results when considering raw signals, LDF and PPG components seem to give different information regarding vascular regulatory phenomena and, therefore, record different responses to hyperoxia.

\section{Acknowledgements}

The authors would like to express their thanks to all the volunteers for their participation in this study.

This work is partially supported by national funds from FCT - Fundação para a Ciência e a Tecnologia, I.P., within the project UID/DTP/04567/2016." minuiu em ambos os sinais. Embora esta diminuição não tenha sido estatisticamente significativa, ela é apoiada por resultados anteriores que sugerem que a hiperóxia inibe a NO sintase e cria espécies de oxigénio reactivas (ERO) que reagem com o NO, destruindo-o, diminuindo assim a vasodilatação mediada pelo próprio $\mathrm{NO}^{(18)}$. Quanto à atividade $\mathrm{NO}_{\mathrm{i}}$, ela mostrou uma diminuição na FLD, mas um aumento na FPG. Esta discrepância pode ser explicada pelas diferenças nas profundidades de medições de ambas as técnicas, sendo que vasos a diferentes profundidades mostram diferenças no calibre e, por conseguinte, podem reagir de forma diferente ao mesmo estímulo. As atividades cardíaca, respiratória, miogénica e $\mathrm{NO}_{\mathrm{d}}$ da $\mathrm{FPG}$ não regressaram aos seus valores basais, como observado a partir das diferenças significativas entre as fases III e I. Já para a FLD, todas as atividades voltaram aos valores de linha de base durante a fase III. Um estudo recente mostrou que as componentes de baixa frequência de FLD e FPG estão correlacionadas positivamente ${ }^{(19)}$. No entanto, neste estudo não foi aplicado nenhum teste de provocação, e os resultados foram registados na posição de supinação. Os nossos resultados sugerem, portanto, que (1) embora estes sinais em bruto deem informações semelhantes, uma análise mais detalhada por TW sugere que eles podem medir fenómenos diferentes e, portanto, podem não ser totalmente substituíveis; e que (2) os testes de provocação pode alterar a organização espectral destes sinais, o que pode explicar as discrepâncias observadas.

\section{Conclusões}

Estes resultados vêm reforçar a utilidade da TW na decomposição de sinais fisiológicos complexos. Em particular, destacam a complexidade da resposta vascular ao oxigénio a $100 \%$, o que parece ser dependente da profundidade de medição. Embora deem resultados semelhantes quando se consideram sinais brutos, as componentes de FLD e FPG parecem dar informações diferentes sobre os fenómenos de regulação vascular e, portanto, respondem de forma diferente à hiperóxia.

\section{Agradecimentos}

Os autores gostariam de expressar os seus agradecimentos a todos os voluntários pela sua participação neste estudo.

Este trabalho é parcialmente financiado por fundos nacionais através da FCT - Fundação para a Ciência e a Tecnologia, I.P., no âmbito do projeto UID/ DTP $/ 04567 / 2016$ 


\section{Conflict of interests}

The author declares that there is no personal or financial relationship that can be understood as presenting a potential conflict of interest.

\section{Conflito de interesses}

O autor declara não existir qualquer relação pessoal ou financeira que possa ser entendida como representando um potencial conflito de interesses.

\section{References / Referências}

1. Holowatz LA, Thompson-Torgerson CS, Kenney WL. The human cutaneous circulation as a model of generalized microvascular function. J Appl Physiol, 2008;105(1):370-2.

2. Rodrigues LM, Pinto PC, Magro JM, Fernandes M, Alves J. Exploring the influence of skin perfusion on transepidermal water loss. Skin Res Technol. 2004 Nov;10(4):257-62.

3. Fung MT, Raine A, Loeber R, Lynam DR, Steinhauer SR, Venables PH, Stouthamer-Loeber M. Reduced electrodermal activity in psychopathy-prone adolescents. J Abnorm Psychol. 2005; 114(2):187-96.

4. Silva H, Ferreira H, Bujan MJ, Rodrigues LM. Regarding the quantification of peripheral microcirculation--Comparing responses evoked in the in vivo human lower limb by postural changes, suprasystolic occlusion and oxygen breathing. Microvasc Res 2015;99:110-7.

5. Anderson KJ, Harten JM, Booth MG, Kinsella J. The cardiovascular effects of inspired oxygen fraction in anaesthetized patients. Eur J Anaesthesiol. 2005; 22(6):420-5.

6. Mahe G, Liedl DA, McCarter C, Shepherd R, Gloviczki P, McPhail IR, Rooke TW, Wennberg PW. Digital obstructive arterial disease can be detected by laser Doppler measurements with high sensitivity and specificity. J Vasc Surg 2014; 59(4):1051-1057.

7. Sahni R. Noninvasive monitoring by photoplethysmography. Clin Perinatol. 2012; 39(3):573-83

8. Silva H, Ferreira H, Rodrigues LM. Studying the Oscillatory Components of Human Skin Microcirculation. Measuring the Skin, pp 1-15

9. Sviridova N, Sakai K. Human photoplethysmogram: new insight into chaotic characteristics. Chaos, Solitons \& Fractals 2015; 77: 53-63

10. Beck TW, Housh TJ, Johnson GO, Weir JP, Cramer JT, Coburn JW, Malek MH. Comparison of Fourier and wavelet transform procedures for examining mechanomyographic and electromyographic frequency versus isokinetic torque relationships. Electromyogr Clin Neurophysiol 2005;45(2):93-103.

11. World Medical Association Declaration of HelsinkiEthical Principles for Medical Research Involving Human Subjects. JAMA. 2013;310(20):21912194.

12. Kvandal P, Landsverk SA, Bernjak A, Stefanovska A, Kvernmo HD, Kirkebøen KA. Low-frequency oscillations of the laser Doppler perfusion signal in human skin. Microvasc Res. 2006;72(3):120-7.

13. Stefanovska A and Krošelj P 1997 Correlation integral and frequency analysis of cardiovascular functions Open Syst. Inf. Dyn. $4457-78$

14. Bollinger A, Yanar A, Hoffmann U, Franzeck U. Is High-Frequency Flux Motion due to Respiration or to Vasomotion Activity? In: Vasomotion and Flow Motion. Karger Publishers, Basel;1993.

15. Kastrup, J., Buhlow, J., Lassen, N.A., 1989. Vasomotion in humans skin before and after local heating recorded with laser Doppler flowmetry. A method for induction of vasomotion. Int. J. Microcirc. Clin. Exp. 8, 205-215

16. Harder DR, Narayanan J, Gebremedhin D. Pressure-induced myogenic tone and role of 20-HETE in mediating autoregulation of cerebral blood flow. American Journal of Physiology-Heart and Circulatory Physiology 2011;300(5):H1557-H65.

17. Seals DR, Johnson DG, Fregosi RF. Hyperoxia lowers sympathetic activity at rest but not during exercise in humans. American Journal of PhysiologyRegulatory, Integrative and Comparative Physiology. 1991;260(5):R873-R8.

18. Hsieh H-J, Liu C-A, Huang B, Tseng AH, Wang DL. Shear-induced endothelial mechanotransduction: the interplay between reactive oxygen species (ROS) and nitric oxide (NO) and the pathophysiological implications. Journal of Biomedical Science. 2014;21(1):1

19. Mizeva I, Di Maria C, Frick P, Podtaev S, Allen J. Quantifying the correlation between photoplethysmography and laser Doppler flowmetry microvascular low-frequency oscillations. J Biomed Opt 2015, 20(3):037007 